\title{
Keadilan dan Diskriminasi Pajak Terhadap Penggelapan Pajak: Persepsi Wajib Pajak Orang Pribadi
}

\author{
Enggar Pratiwi dan Ronny Prabowo \\ Fakultas Ekonomika dan Bisnis Universitas Kristen Satya Wacana (UKSW) Salatiga \\ Jl. Diponegoro No. 52-60 Salatiga 50711, Indonesia
}

\section{Info Article}

Keywords:

Tax Discrimination; Tax Justice;

Tax Evasion.

ISSN (print) : 2598-7763

ISSN (online): 2598-7771

$\triangle$ Corresponding Author:

Enggar Pratiwi:

Tel. /Fax. 085811119413

E-mail: enggarpratiwi00@gmail.com

\begin{abstract}
Abtract
This study aims to analyze the effect of tax justice and tax discrimination on the perception of individual taxpayers (WPOP) regarding tax evasion. The population of this study is the individual taxpayer registered in the Tax Service Office (KPP) Salatiga. The sampling technique used in this study is incidental sampling at the Tax Service Office (KPP) Salatiga and data obtained by distributing questionnaires as much as 70 questionnaires. Based on the results and conclusions of this study show as follows: (1) tax justice has an influence on the perceptions of individual taxpayers regarding tax evasion, (2) tax discrimination has no influence on the perception of individual taxpayers regarding tax evasion.

Citation: Pratiwi, Enggar, dan Prabowo, Ronny. (2019). Keadilan dan Diskriminasi Pajak Terhadap Penggelapan Pajak: Persepsi Wajib Pajak Orang Pribadi. AFRE Accounting and Financial Review, 2 (1)
\end{abstract}

\begin{abstract}
Abstraks
Penelitian ini memiliki tujuan untuk menganalisis pengaruh keadilan pajak dan diskriminasi pajak terhadap persepsi wajib pajak orang pribadi (WPOP) mengenai penggelapan pajak. Populasi dari penelitian ini adalah wajib pajak orang pribadi yang terdaftar di Kantor Pelayanan Pajak (KPP) Salatiga. Teknik pengambilan sampel yang digunakan pada penelitian ini yaitu insidental sampling pada Kantor Pelayanan Pajak (KPP) Salatiga dan data didapat dengan menyebarkan kuesioner sebanyak 70 kuesioner. Bedasarkan hasil dan simpulan penelitian ini meunjukkan sebagai berikut: (1) keadilan pajak memiliki pengaruh terhadap persepsi wajib pajak orang pribadi mengenai penggelapan pajak, (2) diskriminasi pajak tidak memiliki pengaruh terhadap persepsi wajib pajak orang pribadi mengenai penggelapan pajak,
\end{abstract}

JEL Classification: H20, H26

DOI: https://doi.org/10.26905/afr.v2i1.3008

\section{PENDAHULUAN}

Sistem self assessement yang ada di Indonesia mengharuskan wajib pajak secara aktif melakukan penjumlahan dan penyetoran sendiri kepada Kantor Pelayanan Pajak (KPP). Di satu sisi, sistem ini mendorong masyarakat untuk lebih aktif dan sadar dalam melakukan pembayaran pajak karena sistem ini membuat pembayaran pajak lebih praktis dan mengurangi tugas pemerintah dalam penarikan pajak. Di sisi lain, kepercayaan yang diberikan dari pemerintah tersebut memberikan kesempatan bagi wajib pajak untuk merencanakan penghindaran pajak yang berakibat penghindaran pajak dan penggelapan pajak (tax evasion). Penghindaran pajak merupakan usaha penghindaran pajak yang terutang secara ilegal dengan upaya menyembunyikan keadaan sebenarnya (Pohan, 2013). Dengan adanya penggelapan pajak, wajib pajak dapat memperkecil jumlah pajak yang terhutang. Pemerintah memberikan sistem amnesti pajak, tetapi hal tersebut tidak mengurangi penggelapan pajak. Menurut Alstadsaeter, Johannesen \& Zucman, (2017) mengungkapkan jika mengurangi pajak menggunakan 
amnesti pajak tidak secara legal mengurangi penggelapan pajak. Akibat dari penggelapan pajak adalah terdapat cela pada pendapatan dan kemiskinan yang lebih tinggi, serta progresifitas yang lebih rendah dari sistem pajak penghasilan (Matsaganis \& Flevotomou, 2010).

Wajib pajak melakukan penggelapan pajak disebabkan karena beberapa faktor. Faktor pertama yaitu persepsi keadilan pajak. Beberapa penelitian yang dilakukan tentang keadilan pajak menunjukkan hasil yang tidak konsisten. Temuan penelitian Monica \& Arisman (2018) Suminarsasi (2012), Mujiyati, Rohmawati \& P (2009) menunjukkan jika keadilan pajak tidak mempengaruhi persepsi etika penggelapan pajak. Sedangkan beberapa temuan penelitian lain menunjukkan hasil yang berbeda. Temuan Sariani, Wahyuni \& Sulindawati (2016), Tobing (2015), Kurniawati \& Toly (2014) menunjukkan bahwa keadilan pajak berpengaruh terhadap persepsi penggelapan pajak.

Perlakuan pajak yang berbeda oleh aparat pajak akan cenderung terjadinya penyimpangan perilaku wajib pajak, berupa penggelapan pajak. Perilaku ini akan dianggap sesuatu yang etis. Perlakuan yang berbeda merupakan bentuk diskriminasi pajak. Temuan penelitian Monica \& Arisman (2018), Indriyani Nurlaela \& Wahyuningsih (2016) dan Sariani et al., (2016) mengungkapkan bahwa persepsi wajib pajak mengenai etika penggelapan pajak dipengengaruhi positif oleh diskriminasi. Sedangkan Irma (2013) menujukkan temuan yang berbeda, dimana diskriminasi berpengaruh negatif terhadap persepsi wajib pajak atas etika penggelapan pajak.

Temuan penelitian keadilian pajak dan diskriminasi pajak terhadap penggelapan pajak menunjukkan hasil yang tidak konsisten. Sehingga penelitian ini menjadi menarik meneliti kembali hubungan antara keadilan pajak dan diskriminasi terhadap penggelapan pajak. Penelitian ini dilakukan dengan mengambil objek Wajib pajak yang akan diteliti yaitu WPOP di Salatiga yang terdaftar di KPP Salatiga. Tujuan penelitian adalah untuk mengetahui pengaruh apakah keadilan pajak terhadap persepsi WPOP mengenai penggelapan pajak dan untuk mengetahui pengaruh diskriminasi pajak terhadap persepsi WPOP mengenai penggelapan pajak.

\section{PENGEMBANGAN HIPOTESIS}

\section{Keadilan Pajak dan Pengelapan Pajak}

Penggelapan pajak terarah kepada kegiatan tidak benar yang dikerjakan oleh wajib pajak ter- hadap kewajibannya. Usaha wajib pajak dalam penggelapan pajak dapat dilakukan dengan cara menurunkan, menghapuskan, memanipulasi secara ilegal terhadap utang pajak atau terlepas untuk membayar pajak terutang (Rahayu, 2010). Wajib pajak melalaikan peraturan formal perpajakan, meniru dokumen, atau memasukan data dengan tidak lengkap dan tidak benar. Beberapa faktor seperti keadilan dan diskriminasi dapat mempengaruhi pe-rilaku wajib pajak dalam melakukan penggelapan pajak.

Di Indonesia, keadilan dianggap berkaitan dengan hak dan kewajiban wajib pajak, yang memiliki tujuan untuk menciptakan masyarakat yang adil dan makmur. Mardiasmo (2009) mengungkapkan bahwa mencapai keadilan, undang-undang dan pelaksanaan pemungutan harus adil yang harus selaras dengan tujuan hukum. Dalam hal ini, keadilan dilihat dalam kemampuan masyarakat membayar pajak, apakah pemerintah sudah menerapkan pajak secara umum dan merata.

Keadilan pajak dapat mempengaruhi penggelapan pajak karena keadilan pajak dapat mengubah perilaku masyarakat yang dapat membuat wajib pajak melakukan penggelapan pajak. Semakin rendah keadilan pajak, maka tingkat kepatuhan akan semakin menurun, yang berarti kecenderungan melakukan penggalapan pajak semakin tinggi. Temuan Sariani et al., (2016), Tobing (2015), Kurniawati \& Toly (2014) menunjukkan persepsi wajib pajak tentang penggelapan pajak dipengaruhi oleh keadilan. Persepsi keadilan pajak berpengaruh terhadap penggelapan pajak. Menurut Permatasari, (2013) pemungutan pajak harus bersifat final, adil dan merata, yaitu pajak dikenakan kepada orang pribadi harus seimbang dengan kesanggupan dalam pembayaran pajak dan sesuai dengan manfaat yang diterima. Peneliti Torgler B; Valey NT (2010) mengungkapkan bahwa korupsi dan penggelapan pajak banyak dilakukan oleh perempuan.

Keadilan pajak dapat dilihat dari perilaku pemerintah terhadap masyarakat yang akan mempengaruhi perilaku masyarakat dan dapat melakukan penggelapan pajak. Semakin rendah tingkat keadilan, tindakan penggelapan pajak akan cenderung dilihat sebagai perilaku yang cenderung benar, sedangkan semakin tinggi tingkat keadilan sehingga tindakan penggelapan pajak dilihat sebagai perilaku yang tidak benar.

$\mathrm{H}_{1}$ : Keadilan pajak tidak berpengaruh terhadap persepsi wajib pajak orang pribadi mengenai penggelapan pajak. 


\section{Diskriminasi Pajak dan Pengelapan Pajak}

Diskriminasi didalam perpajakan dapat berupa peraturan perpajakan yang dibuat oleh pemerintah tidak adil, dalam arti peraturan tersebut menguntungkan pihak-pihak tertentu, atau diskriminasi dari sisi tindakan terhadap seluruh wajib pajak (Silaen, Basri, \& Azhari, 2015). Masyarakat membutuhkan ketetapan bahwa mereka menerima perilaku adil dalam pemungutan pajak oleh negara.

Ketika terdapat perilaku diskriminasi yang dilakukan oleh aparat pajak, maka akan memunculkan pemikiran yang buruk kepada apparat pajak, sehingga dapat membuat wajib pajak melakukan penggelapan pajak. Temuan Sariani et al., (2016) dan Monica \& Arisman (2018) menunjukkan persepsi wajib pajak atas penggelapan pajak dipengaruhi diskriminasi. Diskriminasi yang dilakukan oleh pemerintah dapat mempengaruhi tindakan masyarakat, dimana pemerintah yang membeda-bedakan lapisan masyarakat dapat memotivasi masyarakat melakukan penggelapan pajak. Semakin tinggi tingkat diskriminasi pajak yang dilakukan pemerintah akan memacu tindakan penggelapan pajak dianggap benar, dan sebaliknya semakin rendah tingkat diskriminasi, maka tindakan penggelapan pajak tidak benar.

$\mathrm{H}_{2}$ : Diskriminasi pajak berpengaruh terhadap persepsi wajib pajak orang pribadi mengenai penggelapan pajak.

\section{DATA DAN METODE}

Dalam penelitian ini, peneliti menggunakan satu variabel dependen dan dua variabel independen. Jenis penelitian ini adalah kuantitatif. Teknik pengumpulan data dilakukan dengan menyebar kuesioner di KPP Salatiga. Responden penelitian sebanyak 70. Analisis penelitian ini menggunakan model regresi linear berganda.

Teknik sampel memakai insidental sampling pada KPP Salatiga, yaitu wajib pajak orang pribadi yang kebetulan bertemu dengan peneliti digunakan untuk sampel dan memenuhi kriteria sebagai sumber penelitian. Sampel yang digunakan adalah WPOP di wilayah Salatiga.

Variabel independen atau variabel bebas dalam penelitian ini adalah keadilan dan diskriminasi. Sedangkan variabel dependen atau variabel terikat pada penelitian ini adalah persepsi WPOP mengenai penggelapan pajak. Operasional varibel disajikan pada tabel 1. Responden akan memberikan jawaban dan diukur menggunakan skala likert dengan pemberian skor 1 sampai 5 dengan jawab sangat setuju sampai sangat tidak setuju.
Seluruh variabel diukur menggunakan skala likert, yaitu 1 = Sangat Tidak Setuju (STS); 2 = Tidak Setuju (TS); 3 = Netral (N); 4 = Setuju (S); 5 = Sangat Setuju (SS).

Tabel 1. Operasionalisasi Variabel Penelitian

\begin{tabular}{|c|c|c|}
\hline Variabel & $\begin{array}{l}\text { Definisi Operasion- } \\
\text { al }\end{array}$ & Indikator \\
\hline $\begin{array}{l}\text { Persepsi } \\
\text { Keadilan } \\
\text { Pajak (X1) }\end{array}$ & $\begin{array}{l}\text { Masyarakat memer- } \\
\text { lukan suatu kepas- } \\
\text { tian bahwa mereka } \\
\text { mendapatkan per- } \\
\text { lakuan yang adil } \\
\text { dalam pengenaan } \\
\text { dan pemungutan } \\
\text { pajak oleh negara } \\
\text { (Friskianti \& Han- } \\
\text { dayani, 2014). }\end{array}$ & $\begin{array}{l}\text { Pajak yang disetor se- } \\
\text { suai manfaat yang di- } \\
\text { peroleh, pajak sesuai } \\
\text { kemampuan dalam } \\
\text { membayar kewajiban } \\
\text { pajak, peraturan Un- } \\
\text { dang-undang perpa- } \\
\text { jakan yang dibuat } \\
\text { sudah adil (Friskianti \& } \\
\text { Handayani, 2014). }\end{array}$ \\
\hline $\begin{array}{l}\text { Persepsi Dis- } \\
\text { kriminasi } \\
\text { Pajak (X2) }\end{array}$ & $\begin{array}{l}\text { Diskriminasi pajak } \\
\text { merupakan perbe- } \\
\text { daan perlakuan da- } \\
\text { ri peraturan perpa- } \\
\text { jakan dan perla- } \\
\text { kuan aparat perpa- } \\
\text { jakan (Rahman } \\
\text { Irma, 2013). }\end{array}$ & $\begin{array}{l}\text { Perbedaan perlakuan, } \\
\text { kepemilikan } \\
\text { Pokok Womor } \\
\text { (NPWP) Pajib } \\
\text { Irma, 2013). }\end{array}$ \\
\hline $\begin{array}{l}\text { Persepsi } \\
\text { WPOP } \\
\text { Mengenai } \\
\text { Penggelapan } \\
\text { Pajak (Y) }\end{array}$ & $\begin{array}{l}\text { Suatu anggapan } \\
\text { atau definisi yang } \\
\text { ada di pemikiran } \\
\text { wajib pajak orang } \\
\text { pribadi pada tinda- } \\
\text { kan yang dilakukan } \\
\text { secara ilegal atau di } \\
\text { luar ketentuan per- } \\
\text { pajakan yang berla- } \\
\text { ku (Rahman Irma, } \\
\text { 2013). }\end{array}$ & $\begin{array}{l}\text { Tidak menyampaikan } \\
\text { Surat Pemberitahuan } \\
\text { Tahunan (SPT), tidak } \\
\text { mendaftarkan diri } \\
\text { NPWP, menyalahgu- } \\
\text { nakan NPWP, tidak } \\
\text { menyetorkan pajak } \\
\text { yang dipungut atau di } \\
\text { potong (Y Friskianti \& } \\
\text { Handayani, 2014). }\end{array}$ \\
\hline
\end{tabular}

Teknik analisis data digunakan model regresi linear berganda. Uji asumsi klasik dilakukan untuk menjamin data penelitian valid, konsisten dan regresi bersifat efisien. Uji asumsi klasik yang digunakan adalah uji normalitas, uji multikolinearitas, dan uji heteroskedastisitas. Adapun rumus dari regresi linier berganda seperti berikut :

$Y=a+\beta_{1} X_{1}+\beta_{2} X_{2}+e$.

Keterangan: $Y=$ Persepsi Wajib Pajak Orang Pribadi; $a=$ Konstanta; $\beta_{1}=$ Koefisien regresi Keadilan dan $\beta_{2}=$ Koefisien regresi Diskriminasi; $X_{1}=$ Keadilan; $X_{2}=$ Diskriminasi dan $e=$ Error

\section{HASIL}

\section{Deskripsi Data Keadilan Pajak}

Persepsi WPOP terhadap Undang-undang atau peraturan pajak. Berdasarkan hasil penyebaran kuesioner diperoleh persepsi WPOP terhadap keadilan Undang-Undang atau peraturan pajak di 
Indonesia disajikan pada tabel 2. Berdasarkan tabulasi data menunjukkan bahwa sebagian besar responden sejumlah 49 responden (70\%) beranggapan bahwa Undang-Undang atau peraturan pajak di Indonesia diatur secara adil.

Tabel 2. Persepsi WPOP Terhadap Undang-Undang dan Pembebanan Pajak

\begin{tabular}{lccclr}
\hline Persepsi & \multicolumn{2}{c}{$\begin{array}{l}\text { Terhadap } \\
\text { dang-Undang }\end{array}$} & \multicolumn{2}{l}{$\begin{array}{l}\text { Terhadap } \\
\text { bebanan Pajak }\end{array}$} \\
& F & $(\%)$ & F & Pem- \\
Persepsi & 0 & 0 & 0 & 0 \\
\hline Sangat Tidak Setuju & 1 & 1,4 & 2 & 2,9 \\
Tidak Setuju & 8 & 11,4 & 8 & 11,4 \\
Netral & 49 & 70,0 & 51 & 72,9 \\
Setuju & 12 & 17,1 & 9 & 12,9 \\
Sangat Setuju & 70 & 100,0 & 70 & 100 \\
Total & & & & \\
\hline
\end{tabular}

Persepsi WPOP terhadap pembebanan pajak sudah didistribusikan secara adil disajikan pada table 2. Hasil penyebaran kuesioner diperoleh persepsi WPOP terhadap pembebanan disajikan pada tabel 2. Berdasarkan hasil analisis menunjukkan sebagian besar responden, yaitu sejumlah 51 (72,9\%) beranggapan bahwa pembebanan pajak didistribusikan secara adil pada setiap wajib pajak. Sedangkan 9 responden (12,9\%) memilih sangat setuju, 8 responden $(11,4 \%)$ memilih netral dan 2 responden $(2,9 \%)$ memilih tidak setuju. Sehingga dapat disimpulkan bahwa pendistribusian pembebanan pajak sudah adil pada setiap wajib pajak.

Persepsi WPOP terhadap pembayaran pajak dan manfaat pajak disajikan pada tabel 3. Berdasarkan hasil analisis menunjukkan pajak yang dibayarkan wajib pajak tidak terlalu tinggi dibandingkan dengan manfaat yang diberikan oleh pemerintah. Hal ini ditunjukkan terlihat dari sebagian besar responden sejumlah 26 responden $(37,1 \%)$ beranggapan bahwa pajak yang harus dibayarkan tidak terlalu tinggi jika dibandingkan dengan manfaat yang diberikan pemerintah.

Berdasarkan hasil analisis data pada tabel 3 menunjukkan bahwa manfaat yang diterima wajib pajak sebagai timbal balik sudah adil. Sebagian besar responden beranggapan bahwa manfaat yang didapat dari pemerintah sebagai timbal balik sudah adil. Hanya $25,8 \%$ yang merasa manfaat yang didapat dari pemerintah sebagai timbal balik kurang adil.

Persepsi WPOP terhadap pembayaran pajak sudah sesuai dengan penghasilan wajib pajak ditunjukkan pada tabel 4. Hasil analisis penyebaran kuesioner diperoleh persepsi WPOP terhadap pembayaran pajak sudah sesuai dengan penghasilan wajib pajak menunjukkan bahwa pembayaran pajak oleh wajib pajak sudah sesuai dengan penghasilan wajib pajak.

Tabel 3. Persepsi WPOP terhadap Pembayaran Pajak dan Manfaat Pajak dan Manfaat yang Diterima Wajib Pajak Sebagai Timbal Balik dan Keadilan Wajib Pajak Sebagai Timbal Balik dan Keadilan

\begin{tabular}{lcccc}
\hline Persepsi & \multicolumn{2}{l}{$\begin{array}{l}\text { Pembayaran } \\
\text { pajak \& Manfaat } \\
\text { pajak }\end{array}$} & \multicolumn{2}{l}{$\begin{array}{l}\text { Manfaat yang Di- } \\
\text { terima Wajib Pajak } \\
\text { Sebagai }\end{array}$} \\
Persepsi & F & $(\%)$ & F & $\begin{array}{l}\text { Timbal } \\
\text { Balik \& Keadilan }\end{array}$ \\
Sangat Tidak Setuju & 2 & 2,9 & 0 & 0 \\
Tidak Setuju & 26 & 37,1 & 9 & 12,9 \\
Netral & 22 & 31,4 & 13 & 18,6 \\
Setuju & 17 & 24,3 & 39 & 55,7 \\
Sangat Setuju & 3 & 4,3 & 9 & 12,9 \\
Total & 70 & 100 & 70 & 100 \\
\hline
\end{tabular}

Sedangkan persepsi WPOP terhadap keadilan tarif pajak menunjukkan bahwa tarif pajak pada setiap wajib pajak tidak sama karena setiap wajib pajak memiliki penghasilan yang berbeda-besar (tabel 4). Besarnya tarif pajak akan menyesuaikan dengan besarnya pendapatan dari masing-masing wajib pajak.

Tabel 4. Persepsi WPOP pembayaran pajak dengan penghasilan wajib pajak dan Keadilan Tarif pajak

\begin{tabular}{lcccc}
\hline Persepsi & \multicolumn{2}{l}{$\begin{array}{l}\text { Pembayaran } \\
\text { pajak dengan } \\
\text { penghasilan }\end{array}$} & $\begin{array}{l}\text { Keadilan } \\
\text { pajak }\end{array}$ & \\
wajib pajak & & \\
Persepsi & $\mathrm{F}$ & $(\%)$ & $\mathrm{F}$ & $(\%)$ \\
\hline Sangat Tidak Setuju & 0 & 0 & 11 & 15,7 \\
Tidak Setuju & 2 & 2,9 & 28 & 40,0 \\
Netral & 2 & 2,9 & 9 & 12,9 \\
Setuju & 54 & 77,1 & 20 & 28,6 \\
Sangat Setuju & 12 & 17,1 & 2 & 2,9 \\
Total & 70 & 100 & 70 & 100 \\
\hline
\end{tabular}

\section{Deskripsi Data Diskriminasi Pajak}

Persepsi WPOP terhadap diskriminasi pajak dibagi menjadi 2, yaitu Persepsi WPOP terhadap perbedaan perlakuan dan persepsi WPOP terhadap kepemilikan NPWP. Kepemilikan NPWP ini terkait dengan kebijakan fiscal luar negeri. Hasil analisis diskriminasi pajak disajikan pada tabel 5. WPOP merasa terjadi perlakuan yang dilakukan oleh pemerintah, dimana 38 atau 54,3\% setuju merasakan adanya diskriminasi perlakuan pajak dan 4 atau $5,7 \%$ sangat setuju. Hal ini menunjukkan $60 \%$ WPOP merasa terjadi perlakukan pajak yang berbeda. Kondisi yang relatif sama terjadi pada diskriminasi pada kebijakan fiskal luar negeri terkait kepemilikan NPWP. Sebagian besar responden $55,7 \%$ merasa ada perlakuan yang berbeda untuk 
kepemilikan NPWP pada kebijakan fiscal ke luar negeri.

\section{Diskriminasi Penggelapan Pajak}

Persepsi WPOP terhadap tindakan penggelapan pajak disajikan pada tabel 6. Tindakan peng-gelapan pajak dapat dilihat dari 4 indikator, yaitu: 1) penyampaian SPT, 2) kepemilikan NPWP, 3) Penyalahgunaan SPT dan 4) tidakan tidak membayar pajak.
Tabel 5. Persepsi WPOP terhadap Diskriminasi Pajak

\begin{tabular}{lcrrr}
\hline Persepsi & $\begin{array}{l}\text { Persepsi Perbedaan } \\
\text { Perlakuan }\end{array}$ & \multicolumn{2}{l}{$\begin{array}{l}\text { Kepemilikan } \\
\text { NPWP }\end{array}$} \\
& F & F & \\
& & $(\%)$ & & \\
\hline Sangat Tidak Setuju & 0 & 0 & 0 & 0 \\
Tidak Setuju & 16 & 22,9 & 12 & 17,1 \\
Netral & 12 & 17,1 & 17 & 24,3 \\
Setuju & 38 & 54,3 & 39 & 55,7 \\
Sangat Setuju & 4 & 5,7 & 2 & 2,9 \\
Total & 70 & 100 & 70 & 100 \\
\hline
\end{tabular}

Tabel 6. Persepsi WPOP terhadap Diskriminasi Penggelapan Pajak

\begin{tabular}{lcccccccc}
\hline Persepsi & \multicolumn{2}{c}{ Penyampaian SPT } & \multicolumn{2}{c}{ Kepemilikan NPWP } & Penyalahgunaan SPT & \multicolumn{3}{c}{ Tindakan Membayar } \\
Pajak
\end{tabular}

Tindakan penggelapan pajak berupa tindakan tidak menyampaikan SPT (tabel 6) menunjukkan sebagian besar responden sejumlah 39 responden $(55,7 \%)$ beranggapan bahwa tindakan tidak menyampaikan SPT merupakan penggelapan pajak. Sedangkan 14 responden $(20,0 \%)$ memilih sangat setuju, 10 responden $(14,3)$ memilih tidak setuju, dan 7 responden $(10,0 \%)$ memilih netral. Sehingga dapat disimpulkan bahwa tindakan tidak menyampaikan SPT merupakan perilaku penggelapan pajak.

Tindakan tidak memiliki NPWP merupakan suatu bentuk tindakan penggelapan pajak. Hal ini ditunjukkan dengan WPOP yang beranggapan bahwa tindakapan tidak memiliki NPWP merupakan penggelapan pajak $(37,1 \%)$.

Sedangkan penyalahgunaan NPWP menurut WPOP juga merupakan bentuk penggelapan pajak. Hal ini ditunjukkan dengan sebagian besar responden yang menyatakan bahwa penyalahgunaan NPWP merupakan bentuk pemnggelapan pajak (58,6\%). Penyalahgunaan NPWP akan cenderung untuk menghindari atau minimal mengurangi beban pajak yang seharus ditanggung. Persepsi WPOP terhadap tindakan tidak membayar pajak.

Berdasarkan hasil analisis yang disajikan pada tabel 6 sebagian besar responden, yaitu sejumlah 48 responden $(68,6 \%)$ beranggapan bahwa tindakan tidak membayar pajak merupakan penggelapan pajak. Sedangkan 15 responden $(21,4 \%)$ memilih sangat setuju, 4 responden $(5,7 \%)$ memilih netral dan 3 responden $(4,3 \%)$ memilih tidak setuju. Sehingga dapat disimpukan bahwa tindakan tidak membayar pajak merupakan penggelapan pajak.

Kuesioner telah melalui uji coba, dimana berdasarkan hasil pengujian validitas instrument (kuesioner) yang telah dilakukan menunjukkan valid dan reliable, sehingga dapat digunakan untuk sebagai instrumen penelitian.

Berdasarkan uji normalitas data menunjukkan data berdistribusi normal. Hal ini ditunjukkan dengan nilai Asymp. Sig. (2-tailed) adalah 0,200 lebih besar dari 0,05 . Hal ini menunjukkan bahwa sebaran data keadilan pajak dan diskriminasi pajak terhadap persepsi wajib pajak orang pribadi mengenai peng-gelapan pajak berdistribusi secara normal.

Uji multikolinieritas menggunakan Variance Inflation Factor (VIF) menunjukkan nilai VIF dari masing-masing variabel bebas lebih kecil dari 10 dan nilai tolerance lebih besar dari 0,1. Berdasarkan nilai VIF dan tolerance, kolerasi di antara variabel bebas dapat dikatakan mempunyai kolerasi yang lemah. Hal ini menunjukkan tidak terjadi multikolinearitas pada model regresi linier.

Hasil dari uji t yang disajikan pada tabel 7 menunjukkan bahwa hipotesis keadilan pajak tidak berpengaruh terhadap persepsi wajib pajak orang pribadi mengenai penggelapan pajak ditolak. Sedangkan hipotesis diskriminasi pajak berpengaruh terhadap persepsi wajib pajak orang pribadi mengenai penggelapan pajak ditolak. 
Tabel 7. Hasil Analisis Regresi Linear

\begin{tabular}{llllll}
\hline Variabel & Beta & Std. Error & Beta & $\mathrm{t}$ & Sig. \\
\hline Konstansta & 2,978 & 0,665 & & 4,480 & 0,000 \\
Keadilan Pajak & 0,267 & 0,200 & 0,176 & 1,334 & 0,187 \\
Diskriminasi Pajak & $-0,029$ & 0,117 & 0,033 & $-0,248$ & 0,805 \\
$\mathrm{R}^{2}$ & 0,075 & & & & \\
\hline
\end{tabular}

Berdasarkan hasil analisis regresi berganda (tabel 7) menunjukkan bahwa koefisien determinasi regresi berganda $R$ Square 0,075. Hal ini menunjukkan kedialan pajak dan diskriminasi pajak hanya mampu menjelaskan penggelapan pajak relatif kecil, yaitu hanya 5,7\%. Variabel keadilan pajak tidak berpengaruh terhadap penggelapan pajak, demikian juga dengan variabel diskriminasi pajak juga tidak berpengaruh terhadap penggelapan pajak.

\section{PEMBAHASAN}

Pengaruh Keadilan Pajak terhadap Persepsi Wajib Pajak Orang Pribadi Mengenai Penggelapan Pajak

Hasil pada penelitian menunjukkan bahwa keadilan pajak berpengaruh terhadap persepsi wajib pajak orang pribadi mengenai penggelapan pajak. Sistem perpajakan yang tidak adil, sehingga ada yang merasa dirugikan akan cenderung mendorong orang atau wajib pajak untuk melakukan penggelapan pajak. Sebaliknya dengan undangundang atau peraturan pajak yang adil akan mengurangi wajib pajak untuk melakukan penggelapan pajak.

Undang-undang atau peraturan pajak di Indonesia yang dipersepsikan WPOP sudah relatif adil (tabel 2), cenderung membuat wajib pajak tidak melakukan penggelapan pajak. Undang-undang dan peraturan pajak yang dirasakan relatif adil oleh WPOP, akan cenderung membuat perilaku masyarakat wajib pajak melakukan tidak penggelapan pajak.

Persepsi keadilan peraturan pajak yang dirasakan oleh wajib pajak yang adil akan cenderung wajib pajak tidak akan melakukan penggelapan pajak. Secara psikologis dengan peraturan pajak yang adil, maka wajib pajak cenderung tidak akan berperilaku menurunkan atau mengurangi, atau bahkan menghindari beban pajak. Wajib pajak merasa beban pajak telah sesuai dengan beban yang memang seharusnya menjadi bebannya. Wajib pajak dalam hal ini WPOP merasakan bahwa distribusi beban pajak telah sesuai beban pajak (tabel 2). Dengan distribusi beban pajak yang sesuai, sehingga WPOP merasakan peraturan pajak yang adil, akan mendorong perilaku WPOP untuk tidak mela-kukan penggelapan pajak.

Persepsi diskriminasi untuk kepemilikan NPWP untuk kebijakan fiscal luar negeri terkait kepemilikan NPWP merupakan bentuk penggelapan cukup tinggi. Namun demikian diskriminasi ini tidak mendorong perilaku penggelapan pajak.

Hasil penelitian ini didukung dengan persepsi WPOP yang merasakan bahwa beban pajak telah sesuai dengan manfaatnya. Temuan ini diperkuat dengan persepsi WPOP bahwa beban pajak sesuai dengan manfaat pajak. WPOP menyatakan beban pajak yang lebih tinggi dari manfaat sebanyak $37,1 \%$ tidak setuju dan $31,4 \%$ merasakan cukup atau setara antara beban dan manfaat pajak (tabel 2).

Temuan penelitian mendukung penelitian Kurniawati \& Toly (2014) menunjukkan penggelapan pajak dipengaruhi oleh keadilan pajak. Namun, penelitian ini tidak mendukung hasil dari penelitian Suminarsasi (2012) yaitu keadilan tidak berpenga-ruh pada penggelapan pajak. Penelitian ini juga tidak menudukung peneliti Ningsih \& Pusposari (2015) yang menghasilkan bahwa keadilan tidak berpengaruh terhadap persepsi mengenai penggelapan pajak.

\section{Pengaruh Diskriminasi Pajak terhadap Persepsi Wajib Pajak Orang Pribadi Mengenai Penggela- pan Pajak}

Hasil penelitian ini menunjukkan diskriminasi pajak tidak berpengaruh terhadap persepsi wa-jib pajak orang pribadi mengenai penggelapan pajak. Tidak berpengaruhnya diskriminasi pajak dapat dikatakan bahwa di Indonesia sudah tidak terjadi perbedaan perlakuan atau diskriminasi dari aparat.

Temuan ini menunjukkan bahwa perlakuan diskriminasi pajak tidak berdampak pada perilaku wajib pajak untuk melakukan penggelapan pajak. Meskipun WPOP merasa ada perlakukan yang berbeda dari aparat pajak, namun perlakukan tersebut tidak memungkinkan atau mampu mendorong WPOP untuk melakukan penggelapan pajak. Hal ini cenderung terjadi karena responden 
adalah wajib pribadi, dimana beban pajak yang memang tidak memungkinkan untuk melakukan penggelapan. Karakteristik pajak WPOP seperti pajak penghasilan (PPh 21), jika WPOP adalah karyawan atau pegawai secara pajak sudah dilakukan di instansinya. Sehingga walaupun ada diskriminasi berupa perlakukan yang berbeda, tidak akan mendorong perilaku WPOP untuk melakukan pemnggelapan pajak.

Penelitian ini mendukung peneliti Widjaja, Lambey \& Walandouw (2017) juga menghasilkan bahwa diskriminasi tidak mempengaruhi persepsi wajib pajak orang pribadi mengenai penggelapan pajak yang menunjukkan bahwa setinggi apapun tingkat diskriminasi yang dilakukan, penggelapan pajak tetapi tidak benar untuk dilakukan. Tetapi penelitian ini tidak mendukung peneliti Faradiza (2018) yang memiliki hasil bahwa diskriminasi pajak mempengaruhi persepsi wajib pajak orang pribadi mengenai penggelapan pajak.

\section{SIMPULAN DAN SARAN}

Hasil penelitian menunjukkan bahwa keadilan pajak berpengaruh terhadap persepsi wajib pajak orang pribadi mengenai penggelapan pajak. Sedangkan diskriminasi pajak tidak berpengaruh terhadap persepsi wajib pajak orang pribadi mengenai penggelapan pajak. Keadilan pajak yang semakin baik, akan cenderung mengurangi wajib pajak untuk menggelapkan pajak, dalam bentuk menurunkan, menghapuskan, memanipulasi secara ilegal terhadap utang pajak atau terlepas untuk membayar pajak terutang.

Keterbatasan pada penelitian ini yaitu pengambilan data pada bulan Maret dimana wajib pajak orang pribadi hanya berfokus pada pengisian SPT. Sehingga lebih baik pengambilan data dilakukan selain di bulan Maret. Selain itu, pengambilan data hanya berada di wilayah Salatiga saja, maka diharapkan untuk memperluas wilayah penelitian, bukan hanya di Salatiga saja tetapi dapat disebarkan ke Kabupaten Semarang atau wilayah lainnya.

\section{DAFTAR PUSTAKA}

Alstadsaeter A ; Johannesen N \& Zucman G. (2017). Nber Working Paper Series Tax Evasion And Inequality. Retrieved From Http://GabrielZucman.Eu/Leaks.

Faradiza, S. A. (2018). Persepsi Keadilan, Sistem Perpajakan Dan Diskriminasi Terhadap Etika Penggelapan Pajak. Akuntabilitas, 11(1), 53-74. Https://Doi.Org/10.15408/Akt.V11i1.8820
Friskianti, Y \& Handayani. (2014). Pengaruh Self Assessment System, Keadilan, Teknologi Perpajakan, Dan Ketidakpercayaan Kepada Pihak Fiskus Terhadap Tindakan Tax Evasion. Accounting Analysis Journal 3 (4).

Ghozali I. (2011). Aplikasi Analisis Multivariate Dengan Program IBM SPSS 19. Semarang: Badan Penerbit Universitas Diponegoro.

Indriyani, M., Nurlaela, S., \& Wahyuningsih, E. M. (2016). Pengaruh Keadilan, Sistem Perpajakan, Diskriminasi Dan Kemungkinan Terdetek-sinya Kecurangan Terhadap Persepsi Wajib Pajak Orang Pribadi Mengenai Perilaku Tax Evasion. Prosiding Seminar Nasional IENACO, 818-825.

Kurniawati, M., \& Toly, A. A. (2014). Analisis Keadilan Pajak, Biaya Kepatuhan, Dan Tarif Pajak Terhadap Persepsi Wajib Pajak Mengenai Penggelapan Pajak Di Surabaya Barat. Tax \& Accounting Review, 4(2), 1-12.

Mardiasmo. (2009). Perpajakan Edisi Revisi 2009. Yogyakarta: Penerbit Andi.

Matsaganis, M., \& Flevotomou, M. (2010). Distributional Implication Of Tax Evasion In Greece. Hellenic Observatory Papers On Greece And Southeast Europe Greese Paper, (31), 31.

Monica, T., \& Arisman, A. (2018). Pengaruh Keadilan Pajak, Sistem Perpajakan, Dan Diskriminasi Pajak Terhadap Persepsi Wajib Pajak Orang Pribdai Mengenai Etika Penggelapan Pajak (Tax Evasion) (Studi Empiris Pada Kantor Pelayanan Pajak Pratama Seberang Ulu Kota Palembang). Retrieved From Http://Eprints.Mdp.Ac.Id/ 2467/1/Jurnal-2014210069.Pdf

Mujiyati, Rohmawati, F. R., \& P, W. H. R. (2009). Determinan Persepsi Mengenai Etika Atas Penggelapan Pajak (Tax Evasion) (Studi Pada Dosen Dan Mahasiswa Universitas Muhammadiyah Surakarta ). Jurnal Akuntansi, (24600780).

Ningsih, D. N. C., \& Pusposari, D. (2015). Determinan Persepsi Mengenai Etika Atas Penggelapan Pajak (Tax Evasion) (Studi Pada Mahasiswa Jurusan Akuntansi Fakultas Ekonomi Dan Bisnis Universitas Brawijaya). Jurnal Akuntansi.

Permatasari, Inggrid, H. L. (2013). Minimalisasi Tax Evasion Melalui Tarif Pajak (Studi Empiris Pada Wajib Pajak Orang Pribadi Di Wilayah KPP Pratama Pekanbaru Senapelan). Diponegoro Journal Of Accounting, 2(2), 1-10.

Pohan C. A. (2013). Manajemen Perpajakan. Jakarta: PT. Gramedia Pustaka.

Rahayu S. K. (2010). Perpajakan Indonesia Edisi 
Pertama. Yogyakarta: Graha Ilmu.

Rahman Irma. (2013). Pengaruh Keadilan, Sistem Perpajakan, Diskriminasi, Dan Kemungkinan Terdeteksi Kecurangan Terhadap Persepsi Wajib Pajak Mengenai Etika Penggelapan Pajak. Journal Of Chemical Information And Modeling, 53(9), 1689-1699. Https://Doi.Org/10.1017/CBO9781107415324.004

Sariani, P., Wahyuni, M. A., \& Sulindawati, N. L. G. E. (2016). Biaya Kepatuhan Terhadap Persepsi Wajib Pajak Mengenai Etika Penggelapan Pajak (Tax Evasion).

Silaen, C., Basri, Y. M., \& Azhari. (2015). Pengaruh Sistem Perpajakan, Diskriminasi, Teknologi Dan Informasi Perpajakan Terhadap Persepsi WP Mengenai Etika Penggelapan Pajak (Tax Evasion). Jom FEKON, 2, 1-15.

Suminarsasi, W. (2012). Terhadap Persepsi Wajib Pajak Mengenai Etika Penggelapan Pajak (Tax Evasion ) Wahyu Suminarsasi Universitas Gadjah Mada Supriyadi Universitas Gadjah Mada Fairness, Tax System, Discrimination, Ethical Perceptions Of Taxpayer, Tax. 0-29.

Tobing, C. V. L. (2015). Pengaruh Keadilan Pajak, Kualitas Pelayanan Pajak, Kemungkinan
Terdeteksinya Kecurangan, Sanksi Perpajakan, Dan Tarif Pajak Terhadap Persepsi Wajib Pajak Mengenai Penggelapan Pajak. Jom FEKON, 2(NO.2 Oktober 2015), 115.

Torgler B; Valey NT. (2010). Gender And Public Attituted Toward Corruption And Tax Evasion.

Widjaja, P. N. K., Lambey, L., \& Walandouw, S. K. (2017). Pengaruh Diskriminasi Dan Pemeriksaan Pajak Terhadap Persepsi Wajib Pajak Orang Pribadi Mengenai Penggelapan Pajak Di Kota Bitung (Studi Kasus Pada WPOP Yang Ditemui Di KPP Pratama Bitung). Jurnal Riset Akuntansi Going Concern, 12(2), 541-552. 